\title{
MIKÄ IHMEEN OLO?
}

Boud, D. \& Feletti, G. (1999). Ongelmalähtöinen oppiminen. Uusi tapa oppia. Terra Cognita, Helsinki.

Hakapaino.

Mistähän johtuu, että maailmalla jo vuosikymmeniä käytössä ollut ongelmaperustainen oppiminen (problembased learning, PBL) on vasta nyt rantautumassa Suomeen? Ja mistä johtuu, että se on tuntunut kiinnostavan ensin kaikkia muita paitsi kasvatus- tieteilijöitä? Heidänhän olisi pitänyt aikoja sitten oivaltaa uuden oppimis- ja opetustavan arvo ja liittää se osaksi opettajan koulutusta, mitä kautta ongelmaperustaisen oppimisen ideat olisivat levinneet kaikkialle koulutukseen.

Aloitteen tekijöinä ovat olleet lääketieteilijät: aluksi Tampereen yliopistossa, josta ensimmäiset PBL-lääkärit valmistuvat par'aikaa. Kiinnostus on virinnyt myös Helsingin yliopiston lääketieteen tiedekunnassa ja myös Turussa on vastaavaa kokeilutoimintaa. Terveydenhoitoalalla on muutenkin mielenkiintoa PBL-sovelluksiin. Pirkanmaan ammattikorkeakoulun terveydenhuolto-oppilaitoksen fysioterapiakoulutusta toteutetaan ongelmaperustaisen oppimisen ideoiden mukaan ja vastaavat oppilaitokset eri puolella Suomea ovat aloittamassa omia kokeilujaan.

PBL-koulutusohjelmien esikuvina ovat olleet ennen muita Hollannin Maastrichtin ja Kanadan McMasterin yliopistot. Sosiaali- ja terveysalan 
edelläkävijä löytyy lähempää eli Ruotsista, jossa Linköpingin yliopisto on toteuttanut ongelmaperustaista oppimista jo kymmenen vuotta. Sovelluksia löytyy myös teknisen, kaupan ja maataloudenkin aloilta muualta maailmasta, esim. Australiasta, Yhdysvalloista ja muista Pohjoismaista. Esimerkkejä ja sovelluksia on paljon, mutta PBL:n teoriapohjaa kuvaavaa kirjallisuutta on sangen vähän.

Tämä hajanaisuus ja pragmaattisuus näkyy myös Terra Cognitan kustantaman Ongelmalähtöinen oppiminen -kirjan sisällössä. David Boudin ja Grahame Felettin toimittama kirja, The Challenge of Problem-based Learning ilmestyi vuonna 1991. Vuoden 1997 kirjan toisen laitoksen 48 kirjoittajan 33 artikkelilukua olivat oiva kohde Helsingin yliopiston Real-Life Book Translation -kurssin 10 hengen käännöstyöryhmälle. Suomennos on onnistunut kielellisesti varsin hyvin lukuunottamatta joitakin kömmähdyksiä, esimerkiksi sisältöluettelossa Boudista on tullut Boyd. Terminologiaa olisi kannattanut tarkentaa kasvatustieteiden näkökulmasta, jolloin kirjan nimikin olisi voitu suoraan suomentaa Ongelmaperustaisen oppimisen haasteeksi.

\section{Artikkelikokoelman}

nimeksi on annettu Ongelmalähtöinen oppiminen - uusi tapa oppia. Nimen ensimmäisestä osasta muokattu lyhenne OLO maistuu lievästi sanottuna oudolta PBL -lyhenteeseen tottuneiden suussa. Kirjan takakannessa väitetään teoksen olevan ensimmäinen suomenkielinen kirja, “jossa OLOa käsitellään laajasti ja asiantuntevasti menetelmän käytöstä saatujen kokemusten perusteella“. Ensimmäinen ongelmaperustaista oppimista käsittelevä kirja ilmestyi suomeksi jo vuotta aikaisemmin nimellä 'Ongelmaperustainen oppiminen - uusi tapa oppia ja opettaa?' perustuen Sari Poikelan lisensiaattitutkimukseen, joka on selkeä kasvatustieteellinen kannanotto PBL:n teoriaperusteisiin ja sovellusmahdollisuuksiin. Tämä kirja on löytänyt käyttäjänsä, koskapa siitä on otettu jo toinen painos, mikä on varsin harvinaista opinnäytetöihin perustuvissa yliopistollisissa julkaisuissa.

\section{Boudin ja Felettin kirja} jakautuu kuuteen osaan. Ongelmaperustaisen oppimisen lähtökohtia kuvaa ensimmäisen osan kolme artikkelia, joissa pyritään osoittamaan, että kyse ei ole vain menetelmästä vaan oppimistavasta eikä pelkästään oppimistavasta vaan myös opetussuunnitelman perusteista. PBL:ssä on kyse haasteesta, joka alkaa "keksimisestä" eli tieteellisestä oivalluksesta oppimisen perusteena. Sanomana on, että PBL on aidosti oppimiskeskeinen lähestymistapa, jossa myös opettaja on aidosti ohjaajan roolissa. Opetussuunnitelman ytimenä on työskentelytapa, jonka lähtökohtana on ajatus, että ongelman ratkaisua varten opiskelijoiden pitää etsiä tietoa ja käsitellä sitä yhteisissä ryhmäistunnoissa eli tutoriaaleissa.

\section{Tietoa ei käsitetä}

sellaisenaan omaksuttavaksi väite- tai tositiedoksi, vaan se on myös asiantuntijatietoa, jolloin ei riitä, että tietää mitä tehdään, vaan on tiedettävä myös miten tehdään. Lähes neljäsataa sivua käsittävässä kokoelmassa PBL:n teoriaperustelut jäävät kuitenkin vain 25 sivun varaan, jotka nekin ovat varsin käytäntökeskeisiä. Tietokäsitys perustellaan lyhyesti ja oppimiskäsitykseen liittyvää pohdiskelua kirjassa on vieläkin niukemmin, mikä joko heijastaa kasvatustieteilijöiden passiivisuutta aihealueen suhteen tai kuvastaa kirjoittajien kasvatustieteellisen asiantuntemuksen vähäisyyttä.

\section{Toisen osan viisi}

artikkelia kuvaavat ongelmaperustaisen opetuksen käynnistämistä muun muassa otsikoilla "Hitaasti mutta varmasti ongelmalähtöiseen oppimiseen" tai "Siirtyminen ongelmalähtöiseen opetukseen 15 kuukaudessa“. PBL:n käyttöönoton syy on yksinkertainen: tarvitaan muutosta, koska opiskelijat ovat tyytymättömiä perinteiseen opetukseen ja koska tulevilta ammattilaisilta vaaditaan muutakin kuin teknistä ja faktatiedon osaamista. Käynnistäminen ymmärretään yleisesti muutoksen vaikeutena, osa opettajista vastustaa, osa seuraa ja aktiiveilta vaaditaan peräänantamatonta sitkeyttä. Hyväkään suunnittelu ei riitä, vaan tarvitaan muutosstrategiaa, resursseja, johtajuutta ja konsultaatiota, joiden avulla asenteet muutetaan ja esteet poistetaan.

\section{Kolmas osa käsittelee} ongelmaperustaisen oppimisen suunnittelua ja toteutusta Kahdeksan artikkelin kuvaukset vaihtelevat potilastapausten valinnasta ja tapausten kirjoittamisesta ongelmien lähtökohdiksi oppimisen hy- 
bridimalliin ja opettajien PBL:ään perehdyttämisen vaikeuksiin. Hybridimalli osoittautuu kuitenkin vain hienoksi nimeksi: ero aikaisempaan on siinä, että kontaktitunteja ja luentoja on vähemmän ja että jäljelle jäävät monitieteiset luennot ja laboratoriotyöt ajoitetaan paremmin ja suhteutetaan tapauksiin, joita käsitellään viikottaisissa PBL-istunnoissa. Hybridin käsitettä on haluttu käyttää, koska PBL nähdään eräänlaisena vanhan ja uuden risteytyksenä.

\section{Myös suomentajat ovat} kantaneet kortensa kekoon uusien käsitteiden kehittelijöinä. "Toisto-OLO" on käännös termistä "closed loop" (Barrows 1986), jolla kääntäjät tarkoittanevat lähinnä oppimisen vahvistamisen ja tehokkuuden arvioimiseen liittyvää "toistosilmukkaa". Toisto-OLOa perustellaan konstruktivismilla, johon kuuluu kirjoittajan mukaan moninaisuuden, aktiivisuuden, mukauttamisen ja sopeutumisen, autenttisuuden, sanallisen ilmaisun ja jatkuvuuden periaatteet. Ilmeisestikin kyse on reflektiosta ja arviointiprosessista, joiden tulkinnassa kirjoittaja ei ole kyennyt irtautumaan behaviorismin ja systeemiteorian palautesilmukan käsitteestä. Seuraava kielikukkanen on ongelmalähtöinen itseohjautuva opiskelu eli OLIOO, jossa on yksinkertaisesti kyse yhteistoiminnallisesta oppimisesta pienryhmissä.

\section{Kirjan neljäs osa käsittelee} ongelmaperustaisen oppimisen sovelluksia eri ammateissa. 8 esimerkkiartikkelin mukaan lääke- ja terveystieteellisten sovellusten lisäksi PBL:ää voi- daan käyttää koneenrakennuksen, sosiaalialan, kaupan, optometrian, sairaanhoidon, arkkitehtuurin ja rakennustöiden, teollisuuden, lakitieteen ja liikkeenjohdon alalla. Aluksi oletettiin, että sovellukset ovat mahdollisia vain korkeakoulutuksessa ja asiantuntijaammateissa, mutta vähitellen on käynyt selväksi, että ongelmaperustaista oppimista voidaan hyödyntää miltei kaikilla koulutusaloilla.

\section{PBL ei ole mahdotonta}

yhteiskuntatieteissäkään, mitä osoittaa vaikkapa Tanskan Roskilden yliopiston ongelmaorientoitunut lähestymistapa, jossa opetus lähtee opiskelijoiden valitsemista ongelmista ja on luonteeltaan tutkivaa alusta loppuun saakka. Ongelmasuuntautuneet (problem-oriented) ja ratkaisukeskeiset (problem-solved) lähestymistavat on kuitenkin haluttu kirjassa rajata ongelmaperustaisen oppimisen ulkopuolelle, mikä tuntuu kummalliselta, koska muutoin PBL:ksi on kelpuutettu miltei mitkä tahansa ongelmointia tarkoittavat opetuskokeilut.

\section{Viidennen osan viisi} artikkelia keskittyvät opiskelijoiden ja koulutusohjelmien arvioinnin vaikeuksiin. Tuottaako ongelmaperustainen oppiminen parempia tuloksia kuin perinteinen opetus? Esimerkiksi lääkärikoulutuksessa yleisin vastaus on, että PBL tuottaa sisältöjen osalta vähintäänkin samantasoisia ja potilaskeskeisyyden ja vuorovaikutustaitojen osalta parempia lääkäreitä. Ongelmaperustainen oppiminen nostaa voimakkaasti esiin formatiivisen prosessiarvioinnin tarpeen jopa niin, että se tehdään jos- kus summatiivisen tuotos- ja tulosarvioinnin kustannuksella. Ammatillisessa koulutuksessa tähän ei ole kuitenkaan varaa, vaan tietojen hallintaa pyritään mittaamaan säännöllisesti toistuvien testien avulla.

\section{Kun tiedetään, että} opettajia ohjaa opetussuunnitelma ja opiskelijoita arvioinnin organisointitapa, olennaisinta onkin ymmärtää arviointi oppimisen lähteenä, kuten eräässä artikkelissa todetaan. Opiskelijoiden reflektointi- ja arviointitaidot kehittyvät samalla kun he oppivat yhteistyöskentelyn, ongelmanratkaisun, tiedonhankinnan, itseopiskelun ja vuorovaikutuksen taitoja, jolloin he ovat huomattavasti valmiimpia siirtymään työelämään.

\section{Kuudes osa, 'ongelma-} lähtöisen oppimisen tuolla puolen' pyrkii asettamaan ongelmaperustaisen oppimisen kriittiseen valokeilaan. Colin Colesin mukaan PBL on ollut turha mutka opetuksen ja oppimisen alalla, koska se ei ole läheskään niin kehittynyt ja hyvä kuin kontekstuaalisen oppimisen malli, jossa oppiminen asetetaan aina kontekstiinsa ja jossa tieto itsessään on kontekstuaalista ja tiedon käsittely on oppijoiden itsensä vastuulla ja tapahtuu yhteistyöskentelyssä. Ehkä näin on periaatteessa, mutta käytännössä asioilla on taipumus monimutkaistua. Kontekstuaalisenkaan oppimisnäkemyksen soveltaminen ei onnistu ilman kamppailua vanhaa näkemystä ja järjestelmää vastaan. Tässä suhteessa PBL onkin mitä suuremmassa määrin opetuksen muuttamisen strategia eikä pelkkä opetusmetodi. 


\section{8 kirjoittajan}

näkemyksen, mielipiteen ja sovellusesimerkin jälkeen lukijalle on kenties selvinnyt, mihin kaikkeen ongelmaperustainen oppiminen voi liittyä ja millaisia käytännön edellytyksiä ja vaikeuksia sen soveltamisessa on. Samalla tulee kuitenkin entistä epävarmempi olo siitä, millä kriteereillä voidaan määrittää, mikä on ongelmaperustaista oppimista ja mikä ei. Mistä ongelmaperustaisen oppimisen tarpeessa ja soveltamisessa on perustaltaan kysymys? Millainen käsitys maailmasta ja ihmisestä sen taustalta löytyy? Miten se on sijoitettavissa pedagogisiin virtauksiin ja oppimiskäsityksiin? Millaisia ongelmaperustaisen oppimisen malleja on olemassa? Onko kasvatustieteilijöillä mitään sanottavaa asiasta?

\section{Kysymyksiin löytyy} vastauksia tämän kirja-arvion laatineiden kirjoittajien ongelmaperustaista oppimista käsittelevistä yleistajuisista ja tieteellisistä julkaisuista, jotka on lueteltu alla. Esimerkiksi puhuako ongelmalähtöisestä vaiko -perustaisesta oppimisesta. Arvioijien kanta on, että ongelmaperustainen on oikea termi, koska itse ongelmat samoin kuin niiden prosessointi voivat vaihdella. Esimerkiksi Maastrichtin seven jump -malli edustaa annetun ongelman käsittelyn kognitiivis-rationaalista ja tässä mielessä ongelmalähtöistä mallia. Linköpingin kokemukselliseen oppimiseen perustuva skenaariomalli sen sijaan edellyttää opiskelijoilta myös opiskelun kohteeksi nousevan ongelman löytämistä, jolloin on mielekkäämpää puhua ongelmaperustaisesta oppimisesta.
Malleja on muitakin, mutta Boudin ja Felettin toimittamat artikkelit eivät niitä esittele, kuten eivät edellä mainittujakaan, vertailusta puhumattakaan. Niinpä suuri osa kirjan sisällöstä on jo vanhentunutta, mutta kieltämättä artikkeleista saa käsityksen mitä PBL:stä on ajateltu ja miten kokeiltu 1980-luvulla sekä miten oppiminen ja opetus on mielletty kasvatustieteen ulkopuolella vielä 1990-luvulla.

\section{Esa ja Sari Poikela}

\section{Perustietoa aiheesta}

POIKELA, S. (1998). Ongelmaperustainen oppiminen. Uusi tapa oppia ja opettaa? Ammattikasvatussarja 19. Tampereen yliopiston opettajankoulutuslaitos. Hämeenlinna. Jäljennepalvelu.

POIKELA, E. \& Poikela, S. (1999). Kriittisyys ja ongelmaperustainen oppiminen. Julkaisussa Järvinen-Taubert, J. \& Valtonen, P. (toim.). Kriittisyyteen kasvu korkeakoulutuksessa. Tampere. Juvenes-Print. Tampereen yliopistopaino Oy.

POIKELA, E. \& Poikela, S. (1997). Conceptions of Learning and Knowledge - Impacts on the Implementation of ProblemBased Learning. In Eitel, F. and Gijselaers, W. (ed.) Problembased Learning. Theory, Practice and Research Zeitschrift für Hochschuldidatik. Beiträge zu Studium, Wissenschaft und Beruf. Innsbruck-Wien. StudienVerlag. Heft 1/1997.

\section{Muut julkaisut}

POIKELA, E. (1996). Ongelmaperustainen oppiminen tulee ovatko oppilaitokset ja kirjastot valmiina. Julkaisussa Niinikangas, L. (toim.) Kipinöitä oppimiseen - kirjasto oppimisen tukena Ammattikasvatushallinnon koulutuskeskus. 1/ 1996.
POIKELA, E. \& Poikela, S. (1997). Ongelmaperustainen oppiminen - strategia vai metodi. Fysioterapia 2/1997.

POIKELA, S. \& Poikela, E. (1997). Ongelmaperustainen oppiminen. Aikuiskoulutuksen maailma. 6/1997.

POIKELA, S. \& Öystilä, S. (1996) Ongelmaperustainen oppiminen korkeakouluopetuksessa. Esimerkkinä Tampereen yliopiston lääkärikoulutus. Korkeakoulutieto 2/1996. 